\title{
IMPLEMENTASI ALGORITMA HORSPOOL PADA APLIKASI ISTILAH FASHION
}

\author{
Azhar $^{1}$, Nasib Marbun², Soeb Aripin ${ }^{3}$, Efori Buulolo ${ }^{4}$ \\ ${ }^{1,2}$ Prodi Teknik Informatika, Universitas Sumatera Utara, Medan, Indonesia \\ ${ }^{3,4}$ Prodi Teknik Informatika, STMIK Budi Darma, Medan, Indonesia \\ Email: ${ }^{1}$ Azhar11091993@gmail.com, ${ }^{2}$ Marbunnasib93@gmail.com
}

\begin{abstract}
Abstrak
Kata fashion identik dengan busana, di era digital saat ini memiliki fashion telah menjadi suatu gaya hidup yang dapat memperkenalkan kepribadian melalui fashion di media sosial. Pada isitilah fashion terkandung banyak istilah-istilah yang menjadi dasar pengetahuan untuk menyesuaikan fashion seseorang. Istilah fashion pada umumnya dikaji dengan menggunakan bahasa asing sehingga banyak masyarakat awam sulit untuk mengerti lebih detail terkait istilah-istilah fashion sehingga diperlukan adanya aplikasi yang mengadopsi ilmu pengetahuan terkait istilah fashion. Sebuah aplikasi yang dibangun dengan tujuan utama untuk melakukan pencarian informasi seperti istilah fashion tidak terlepas dari adanya pencocokan string. Pencocokan string dapat diartikan sebagai aktivitas yang bekerja untuk menyesuaikan sesuatu hal yang dicari pada sebuah wadah dengan isi yang tersimpan pada wadah tersebut. Algortima string matching yang diimplementasikan untuk pencarian arti istilah fashion dalam penelitian ini yaitu algoritma Horspool. Algoritma horspool merupakan algoritma turunan dari boyer-moore, untuk melewati proses ketika terjadi ketidakcocokan karakter pattern dengan karakter text, algoritma horspool menggunakan bad-match secara berulanG hingga seleruh karakter pattern ditemukan memiliki kecocokan terhadap text. Hasil dari aplikasi yang dibangun pada penelitian ini dapat mempermudah masyarakat awam yang kesulitan untuk mencari informasi terkait istilah-istilah fashion dengan lebih mudah.
\end{abstract}

Kata Kunci: Implementasi, Istilah Fashion, Algoritma, Horspool.

\begin{abstract}
The word fashion is synonymous with fashion, in today's digital era fashion has become a lifestyle that can introduce personality through fashion on social media. In the term fashion, there are many terms that form the basis of knowledge to match one's fashion. The term fashion is generally studied using foreign languages so that many ordinary people find it difficult to understand in more detail related to fashion terms so that there is a need for applications that adopt science related to the term fashion. An application that was built with the main objective to search for information such as fashion terms is inseparable from the existence of string matching. String matching can be interpreted as an activity that works to match something that is sought in a container with the contents stored in the container. Algortima string matching which is implemented to search for the meaning of the term fashion in this study is the Horspool algorithm. The horspool algorithm is a boyer-moore derivative algorithm, to go through the process when there is a mismatch of character patterns with text characters, the horspool algorithm uses bad-matches repeatedly until all the character patterns are found to have a match against the text. The results of the application built in this study can facilitate ordinary people who have difficulty finding information related to fashion terms more easily.
\end{abstract}

Keywords: Implementation, Fashion Terms, Algorithms, Horspool

\section{PENDAHULUAN}

Fashion merupakan salah satu tips gaya hidup yang dapat digunakan untuk menyampaian ekspresi diri seseorang kepada orang lain [1]. Kata fashion identik dengan busana, di era digital saat ini memiliki fashion telah menjadi suatu gaya hidup yang dapat memperkenalkan kepribadian melalui fashion di media sosial. Pada isitilah fashion terkandung banyak istilah-istilah yang menjadi dasar pengetahuan untuk menyesuaikan fashion seseorang. Istilah fashion pada umumnya dikaji dengan menggunakan bahasa asing sehingga banyak masyarakat awam sulit untuk mengerti lebih detail terkait istilah-istilah fashion sehingga diperlukan adanya aplikasi yang mengadopsi ilmu pengetahuan terkait istilah fashion.

Di era digital saat ini aplikasi penggunaan suatu aplikasi telah menjadi kebutuhan bagi manusia untuk mempermudah penyelesaian masalah. dalam hal ini di dalam sebuah aplikasi yang dibangun dengan tujuan utama untuk melakukan pencarian informasi seperti istilah fashion tidak terlepas dari pencocokan string. Pencocokan string dapat diartikan sebagai aktivitas yang bekerja untuk menyesuaikan sesuatu hal yang dicari pada sebuah wadah dengan isi yang tersimpan pada wadah tersebut. Algortima string matching yang diimplementasikan untuk pencarian arti istilah fashion pada penelitian ini yaitu algoritma Horspool.

Algoritma horspool merupakan algoritma turunan dari boyer-moore yang melakukan pencocokan string dimulai dari karakter paling kanan dari pattern yang akan dicocokan dengan text, algoritma ini dibuat oleh R. Nigel Horspool tepatnya pada tahun 1980 [2]. Untuk melewati proses ketika terjadi ketidakcocokan karakter pattern dengan karakter text, algoritma horspool menggunakan bad-match secara berulanh hingga seleruh karakter pattern ditemukan memiliki kecocokan terhadap text [3]. Hasil dari aplikasi yang dibangun pada penelitian ini dapat mempermudah masyarakat awam yang kesulitan untuk mencari informasi terkait istilah-istilah fashion dengan lebih mudah.

\section{TEORITIS}

\subsection{Fashion}


Kata fashion berasal dari bahasa Latin yaitu factio dengan memiliki arti "membuat atau melakukan". Oleh sebab itu, arti kata asli fashion mengacu pada pemikiran terkait dengan fetish atau obyek fetish [4]. Fashion sendiri dapat diartikan sebagai budaya berpakaian yang dapat dijadikan oleh masyarakat pada umumnya sebagai gaya atau style sesorang untuk menyengekspresikan diri di lingkungan hidupnya. Kata fashion identik dengan busana yang dimana dapat dipilih, diterima, dan digunakan untuk gaya hidup namun tidak lepas dari prioritas kenyamanan dalam menggunakannya [1]

\subsection{String Matching}

String adalah suatu frase, kata, atau kalimat [5]. String matching adalah metode pencocokan karakter yang diadopsi melalui proses input menggunakan keyboard [6]. String matching pada dasarnya terbagi atas dua bagian, yaitu exact matching dan heuristic matching. Exact Matching dapat digunakan untuk menemukan sebuah pattern yang berasal dari suatu text. Menurut klarifikasi berdasarkan arah penccokan string, algoritma exact matching terbagi atas tiga bagian, yaitu :

1. Pencocokan string terhadap text dimulai dari kiri ke kanan.

Algoritma exact matcing pada kategori ini adalah algoritma Knuth Morris Pratt, Brute Force, dan lain-lain.

2. Pencocokan string terhadap text dimulai dari kanan ke kiri.

Algoritma exact matching pada kategori ini yaitu algoritma Horspool, Turbo Boyer-Moore, Boyer Moore, Raita, dan lain-lain.

3. Pencocokan string terhadap text yang arah pergeserannya ditentukan oleh program. Algoritma exact matching pada kategori ini yaitu algoritma Crochemore-Perrin, Colussi dan lain-lain [7].

\subsection{Horspool}

Algoritma horspool merupakan algoritma turunan dari algoritma boyer-moore yang melakukan pencocokan string dimulai dari karakter paling kanan dari pattern yang akan dicocokan dengan text, algoritma ini dibuat oleh R. Nigel Horspool tepatnya pada tahun 1980 [2]. Untuk melewati proses ketika terjadi ketidakcocokan karakter pattern dengan karakter text, algoritma horspool menggunakan bad-match secara berulanh hingga seleruh karakter pattern ditemukan memiliki kecocokan terhadap text. Melakukan pencocokan string menggunakan algoritma horspool terdapat 2 (dua) tahap, yaitu tahap pra processing dan tahap searching [3].

\section{ANALISA DAN PEMBAHASAN}

Kebutuhan terhadap fashion sebagai penunjang gaya hidup seseorang yang tidak terlepas dari penggunaan busana yang nyaman untuk digunakan diperlukan adanya aplikasi khusus untuk mempermudah masyarakat pada umumnya dalam mencari fashion sesuai dengan kepribadian tersendiri. Pada penelitian ini diterapkan algoritma string matching yang dapat bekerja dengan melakukan pencocokan string dengan pencocokan awal dari arah kanan ke arah kiri dengan ketentuan pergeseran karakter berdasarkan nilai pada tabel bad-match pada sebuah aplikasi istilah fashion. Sebagai contoh kasus untuk menyelesaikan permsalahan dalam melakukan pencarian informasi arti istilah fashion pada aplikasi istilah fashion adalah sebagai berikut ini :

Text : HAUTE COUTURE.

Pattern : UTURE

Berdarkan ketentuan text diatas ditemukan nilai bad-match seperti yang terdapat di dalam tabel berikut :

Tabel 1. Bad Match

\begin{tabular}{ccc}
\hline Karakter & Indeks & Nilai \\
\hline $\mathrm{U}$ & 0 & 4 \\
$\mathrm{~T}$ & 1 & 3 \\
$\mathrm{R}$ & 2 & 2 \\
$\mathrm{E}$ & 3 & 1 \\
$*$ & --- & 5
\end{tabular}

Nilai pada Tabel 1.Bad Match di atas diperoleh berdasarkan perhitungan di bawah ini :

Nilai $\mathrm{U}=5-0-1=4$

Nilai $\mathrm{T}=5-1-1=3$

Nilai $R=5-2-1=2$

value $\mathrm{E}=5-3-1=1$

Setelah memperoleh nilai Bad Matct, tahap selanjutnya adalah melakukan tahap pencarian atau pencocokan string sebagai berikut ini :

1. Pencocokan string

Tabel 2. Pencocokan string 1

\begin{tabular}{llllllllllllll} 
Indeks & 0 & 1 & 2 & 3 & 4 & 5 & 6 & 7 & 8 & 9 & 10 & 11 & 12 \\
\hline Text & $\mathrm{H}$ & $\mathrm{A}$ & $\mathrm{U}$ & $\mathrm{T}$ & $\mathrm{E}$ & & $\mathrm{C}$ & $\mathrm{O}$ & $\mathrm{U}$ & $\mathrm{T}$ & $\mathrm{U}$ & $\mathrm{R}$ & $\mathrm{E}$ \\
Pattern & $\mathrm{U}$ & $\mathrm{T}$ & $\mathrm{U}$ & $\mathrm{R}$ & $\mathrm{E}$ & & & & & & & & \\
\hline
\end{tabular}


Pada proses pencocokan karakter E pattern dengan karakter E pada text terjadi kecocokan, maka dilakukan pencocokan pada karakter sebelah kiri yaitu karakter $\mathrm{R}$ pada pattern dengan karakter $\mathrm{T}$ ada text, namun terlihat tidak terjadi kecocokan, maka selanjutnya dilaukan pergeseran sebanyak nilai bad match karakter $\mathrm{T}$ pada text, yaitu 3 langkah

2. Pencocokan string 2

Tabel 3. Pencocokan string 2

\begin{tabular}{llllllllllllll}
\hline Indeks & 0 & 1 & 2 & 3 & 4 & 5 & 6 & 7 & 8 & 9 & 10 & 11 & 12 \\
\hline Text & $\mathrm{H}$ & $\mathrm{A}$ & $\mathrm{U}$ & $\mathrm{T}$ & $\mathrm{E}$ & & $\mathrm{C}$ & $\mathrm{O}$ & $\mathrm{U}$ & $\mathrm{T}$ & $\mathrm{U}$ & $\mathrm{R}$ & $\mathrm{E}$ \\
Pattern & & & & $\mathrm{U}$ & $\mathrm{T}$ & $\mathrm{U}$ & $\mathrm{R}$ & $\mathrm{E}$ & & & & & \\
\hline
\end{tabular}

Pada proses pencocokan karakter E pattern dengan karakter O terlihat tidak terjadi kecocokan, maka selanjutnya dilaukan pergeseran sebanyak nilai bad match karakter O. Karena O bukan termasuk bagian dari karakter pattern maka pergeseran dilakukan sebanyak nilai bad match*, yaitu 5 langkah.

3. Pencocokan string 3

Tabel 4. Pencocokan string 3

\begin{tabular}{llllllllllllll}
\hline Indeks & 0 & 1 & 2 & 3 & 4 & 5 & 6 & 7 & 8 & 9 & 10 & 11 & 12 \\
\hline $\begin{array}{l}\text { Text } \\
\text { Pattern }\end{array}$ & $\mathrm{H}$ & $\mathrm{A}$ & $\mathrm{U}$ & $\mathrm{T}$ & $\mathrm{E}$ & & $\mathrm{C}$ & $\mathrm{O}$ & $\mathrm{U}$ & $\mathrm{T}$ & $\mathrm{U}$ & $\mathrm{R}$ & $\mathrm{E}$ \\
& & & & & & & & & $\mathrm{U}$ & $\mathrm{T}$ & $\mathrm{U}$ & $\mathrm{R}$ & $\mathrm{E}$ \\
\hline
\end{tabular}

Pada proses pencocokan karakter E pattern dengan karakter E pada text terjadi kecocokan, karakter $\mathrm{R}$ pattern dengan karakter R pada text terjadi kecocokan, karakter U pattern dengan karakter U pada text terjadi kecocokan, karakter T pattern dengan karakter T pada text terjadi kecocokan, karakter U pattern dengan karakter U pada text terjadi kecocokan, maka proses pencocokan string berhenti pada tahap pencocokan string yang ketiga.

Berikut ini adalah hasil implementasi algoritma horspool pada aplikasi istilah fashion yang dibangun menggunakan bahasa pemrograman visual basic net 2008 untuk mempermudah masyarakat awam yang kesulitan untuk mencari informasi terkait istilah-istilah fashion:

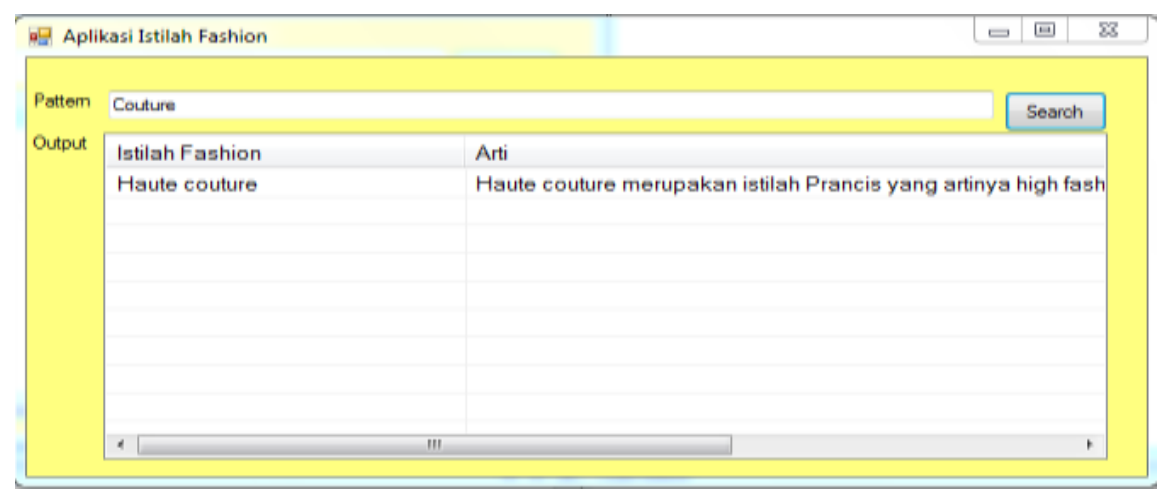

Gambar 1.Aplikasi Istilah Fashion

\section{KESIMPULAN}

Algoritma horspool dapat menemukan kecocokan string dengan cepat seperti yang dilakukan pada contoh kasus pencarian istilah fashion, yaitu dengan menggunakan nilai pergeseran bad match algoritma horspool dapat menemukan kecocokan string dalam tahap ketiga atau tahap pergeseran ketiga.

\section{REFERENCES}

[1] T. Y. Trisnawati, "Fashion sebagai Bentuk Ekspresi Diri dalam Komunikasi," vol. III, pp. 36-47, 2011.

[2] A. A. Yahya, N. A. Hasibuan, and P. Ramadhani, "Indonesian Proverbs Application Design by Applying Android Horspool Boyer Moore Algorithm," vol. 2, no. 1, pp. 32-38, 2018.

[3] V. Frigustini, A. Erlansari, and D. Andreswari, "IMPLEMENTASI ALGORITMA HORSPOOL PADA APLIKASI KAMUS BAHASA LINTANG - INDONESIA BERBASIS ANDROID,” vol. 6, no. 1, pp. 88-104, 2018.

[4] F. Dan, G. Hidup, I. Dan, R. Hendariningrum, and M. E. Susilo, "FASHION DAN GAYA HIDUP : IDENTITAS DAN KOMUNIKASI,” no. January 2008, 2019.

[5] D. Tetap, S. Budi, and D. Medan, "IMPLEMENTASI ALGORITMA STRING MATCHING DALAM PENCARIAN SURAT DAN AYAT DALAM BIBLE BERBASIS ANDROID Efori Buulolo Diterbitkan Oleh : STMIK Budi Darma Medan Diterbitkan Oleh : STMIK Budi Darma Medan,” vol. III, pp. 23-27, 2013.

[6] R. Rahim, "Keylogger Application to Monitoring Users Activity with Exact String Matching Algorithm Keylogger Application to Monitoring Users Activity with Exact String Matching Algorithm," 2018.

[7] N. Marbun, M. Zarlis, D. Hartama, and B. J. D. Sitompul, "Implementasi Algoritma Raita Pada Pencarian Katalog Alkes," pp. 520-523, 2019. 